\title{
Judicial Support and Criminal Sentencing
}

\author{
Tom N. McInnis, University of Central Arkansas
}

This study examines the hypothesis that one reason why criminal trial courts are supported by the public and seen as acting legitimately is that both members of the public and of the judiciary hold common perceptions regarding the principles upon which sentences should be based. It uses Stephenson's Q-Technique and isolates three separate factor types that describe differing subjective views of the sentencing process.

One of the functions of the judicial system is the maintenance of law and order within the society. One important tool that criminal courts have to carry out this responsibility is the sentencing of citizens who are found guilty of committing crimes. The knowledge that all who are convicted of crimes will be sentenced justly not only punishes criminals for their behavior but also serves as a further deterrent to others, thus helping to maintain an orderly society. All of these effects of the sentencing process help to encourage further public support of the criminal courts.

In order for criminal courts to function as a stabilizing agent within the judicial system and maintain public support, it can be assumed that the public must view them as legitimate. Easton has commented on the connection between legitimacy and public support:

The inculcation of a sense of legitimacy is probably the single most effective device for regulating the flow of diffuse support in favor both of the authorities and of the regime. ... [T]he most stable support will derive from the conviction on the part of the member that it is right and proper for him to accept and obey the authorities and to abide by the requirements of the regime. It reflects the fact that in some vague or explicit way he sees these objects as conforming to his own moral principles, his own sense of what is right and proper in the political sphere (Easton 1965, 278).

To maintain stability and legitimacy within government it also has been suggested by democratic theorists that there must be general agreement, on both substantive and procedural matters, between elites within the government and the general public (Jackman 1981). To maintain stable public support for the actions of American courts we would expect to find common perceptions concerning the administration of justice that link together jurists as well as the general public.

TOM N. MCINNIS is Associate Professor of Political Science at the University of Central Arkansas.

The American Review of Politics, Vol. 15, Autumn, 1994: 361-373

Q1994 The American Review of Politics 
Past research has focused on the ability of the United States Supreme Court to maintain public support. This research has shown that due to the public's relatively low levels of knowledge concerning its activities, the Supreme Court has had little difficulty in maintaining public support (Handberg 1984). Caldeira, however, has challenged this traditional view concerning public ignorance of the Supreme Court's actions. He has suggested that the general public has considerably more knowledge concerning the Supreme Court than previously believed (Caldeira 1986, 1987). Evidence supporting Caldeira's suggestion may be found in earlier studies showing that the public has withdrawn specific support from the Supreme Court when it rendered unpopular decisions, although the diffuse support for the Court remained high (Tanenhaus and Murphy 1981; Jaros and Roper 1980).

Much less research has been conducted regarding public support of state criminal courts than for the United States Supreme Court. Research has shown that the general public has little knowledge of, or experience with, state criminal courts (Yankelovich et al. 1978). Despite this low level of knowledge, there is common agreement between members of the public and the judiciary regarding basic principles of criminal sentencing. These principles loosely include the belief that, during sentencing, judges should take into consideration legal factors, such as whether guilt is acknowledged by the defendant, the number of priors, and the violence involved in the crime. Research also indicates that there is agreement that sentencing should not consider extra-legal factors, including race, social-class of the criminal, age, and sex (Hagan and Bumiller 1983).

The assumption may be forwarded that support for the criminal courts also could be withdrawn if the public disagreed with the sentences imposed by judges, or with the reasoning behind sentences. Such a lack of linkage between the perceptions of the public concerning criminal sentencing and those of the judges who actually perform the sentencing could cause the public to question the legitimacy of the process. This could help explain why past studies have shown that sentences imposed by members of the judiciary in criminal cases sometimes do adjust to stay within the bounds of public opinion, adding to the public's continuing support of criminal courts (Cook 1977, 1979; Kuklinski and Stanga 1979). Agreement between members of the judiciary and the public on what factors should play a role in sentencing decisions should instill a sense of legitimacy in the entire judicial system. If criminal courts act in ways that are approved of by the public, the courts should be capable of enlarging both specific and diffuse support for the entire judicial system.

It may be assumed that in order to maintain public support for the judicial system it is necessary that portions of both the public and the 
judiciary hold similar perceptions concerning the judicial function of sentencing. Despite the assumption that there should be linkage between members of the public and judicial elites, it is too much to expect that all members of the public and the judiciary would have the same perceptions of the judicial sentencing process. In order for the system to operate smoothly and maintain legitimizing public support it may be hypothesized that perceptions about sentencing must cut across both the public and judicial elite. That is, some members of the public and the judiciary must share perceptions in common with both fellow jurists and citizens. This would allow for different, competing perceptions concerning the sentencing process that link members of the judiciary to sectors of the public with whom they share a common sentencing philosophy. Such elite-mass linkage would be a sign of a healthy judicial system in a democratic society. An unhealthy judicial system would be characterized as one in which all the members of the public and the members of the judiciary had different perceptions of the judicial role in sentencing criminals. This situation would threaten the legitimacy of criminal courts by making it seem as though the public were obeying the moral principles of those seated in the judiciary, rather than their own.

In order to test this hypothesis, this pilot study investigates subjective perceptions concerning judicial sentencing by comparing judicial attitudes with those of attentive and less-attentive elements of the public in the state of Missouri. The data were collected in 1989, and concentrate on the sentencing decisions of the members of the Circuit Division of the Circuit Court of Missouri. The Circuit Division of the Circuit Court is a court of original jurisdiction in all felony cases concerning Missouri state law. Circuit Court judges, who are elected, must meet the minimum qualifications of being thirty years old, a citizen of the United States for ten years, a Missouri registered voter for three years, a resident of the circuit for one year, and holding a license to practice law in the state (Hardy 1985, 99).

\section{Research Design}

To determine whether members of the public and judiciary have the same values and attitudes about the sentencing process, Stephenson's Q-technique is used here. The usefulness of this methodology comes from the ability of Q-technique to develop an understanding of people's subjectivity. The Q-technique has already proven itself to be useful in studies of judicial behavior (Casey 1989; Ungs and Baas 1972). Due to individual differences, each person tends to form their own world, to have their own unique norms and base their behavior upon their perceptions. Q-technique 
enables measurement of a person's attitudes or feelings about any complex issue, condition, or situation. It is a technique in which the respondents operationally define their attitude by sorting self-referent statements of opinion.

To draw the Q-samples, a literature review was conducted to collect a large universe of opinion regarding sentencing. The initial Q-population contained 208 statements. Out of these, 46 statements were selected which fit into five subject categories that represented some aspect of the sentencing process. Balance was maintained in the design by selecting a variety of positive, negative, and, in some cases, neutral opinions in the subject categories. This selection allowed the study's subject matter to be brought into focus while allowing boundaries to be placed within the parameters of the research interest (Brown 1980, 38). The Q-sample for the study can be found in Appendix Table 1.

Thompson's design for P-samples was followed (Thompson 1966). This allowed inclusion in the P-sample of four basic groups, including: experts, for which circuit court judges in the state of Missouri are used; authorities, which are represented by members of the legal community (faculty) at the University of Missouri law school, which trains many members of the Missouri bar who eventually become judges; the attentive public, which is represented by academics from the social sciences; and the less-informed public, which is represented by ordinary citizens in the general public. Participants were chosen for convenience with an eye toward representativeness rather than randomness. The total number of participants was small at 31 , but nevertheless adequate to sample the variance of factors within Q-technique. (For a clarification of why small samples are adequate in Q-technique, see the technical note).

The collection of data for Q-technique is based upon the Q-sort. The Q-sort consisted of each respondent sorting through the 46 Q-statements. The forced frequencies of the statements, and the scores given to them for a Q-sort with 46 Q-statements, can be found in Table 1.

Table 1. Forced Frequencies Table

\begin{tabular}{|c|c|c|c|c|c|c|c|c|c|c|}
\hline \multicolumn{3}{|c|}{$\begin{array}{c}\text { Most Agreed } \\
\text { with Statements }\end{array}$} & \multicolumn{5}{|c|}{$\begin{array}{c}\text { Neutral } \\
\text { Statements }\end{array}$} & \multicolumn{3}{|c|}{$\begin{array}{l}\text { Most Disagreed } \\
\text { with Statements }\end{array}$} \\
\hline & & & FORC & FRE & ENC & $\mathrm{ST}_{\mathrm{T}}$ & MEN & & & \\
\hline 2 & 3 & 4 & 5 & 6 & 6 & 6 & 5 & 4 & 3 & 2 \\
\hline \multicolumn{11}{|c|}{ SCORES } \\
\hline+5 & +4 & +3 & +2 & +1 & 0 & -1 & -2 & -3 & -4 & -5 \\
\hline
\end{tabular}


Thirty-one respondents sorted through the 46 statements and these responses were correlated, forming a correlation matrix. The factor-analyzed correlation matrix in turn produced a simple structure matrix (Appendix Table 2). After the correlation matrix was created, the eigen values of $8.6084,3.5952$ and 2.4284 were plotted on a scree plot to determine the number of factors that could be isolated. This showed that a two factor solution was reasonable. However, because there also were negatively-loaded subjects, the two factor solution produced one more factor, resulting in the isolation of three factors showing different perceptions toward judicial sentencing. These three factors may be identified in Appendix Table 2 for the 28 subjects that loaded significantly on one of the factors.

\section{Interpretation}

\section{Judicial Necessity}

The first factor that can be isolated may be elucidated by labelling persons of this type believers in Judicial Necessity. These persons have a strong basic belief in the need for judges in our society. Such necessity comes from the conviction that judicial discretion should be a primary ingredient in the processing of criminals through the criminal justice system. As a result, they disagree with the view that there should be uniform sentences for each crime, thereby eliminating the need for judges in the sentencing process.

Those respondents falling in the category of Judicial Necessity also tend to see a need for judges in the criminal process, stemming from their high opinion of judicial skills and work habits. Respondents in this category think highly of the ability of judges to understand society, the reasons why crimes are committed, and their ability to use this understanding to make sentences that actually help to stop further crime.

The same respondents hold a firm belief in examination of the defendant's prior record. They also think that plea bargaining is a necessary part of the criminal process and should continue as a practice. At the same time, these respondents believe that judges should at least be aware of public opinion in their sentencing decisions.

Despite their view that members of the judiciary do perform their duties in a responsible manner, they also see room for improvement in the system. They acknowledge that there are disparities even when judges agree on the reasoning behind their sentences. They also hold the attitude that more thought should go into the sentencing decision than presently does. Despite these possible problems in the way that the judicial system arrives 
at its decisions, these respondents do not have major questions or problems about the process or its results.

From the demographic data, members of the Judicial Necessity group largely emerge as members of the judiciary or the legal community. All of the members of the judiciary and the legal community that had significant loading factors fit into this category, while only two others loaded on this factor.

\section{Judicial Sceptics}

The second group of respondents that may be typed into a specific factor is labelled Judicial Sceptics. Of the respondents in this study, five loaded on this second factor. The demographic background of these respondents shows that they come from the groups drawn from the public and from academia (viz., the social sciences).

The most distinguishing facet of the subjective perception of these respondents is their disbelief that judges are neutral arbitrators of the law who are more capable of fulfilling their duties than could other members of society. This scepticism derives from their opinion that judges have a difficult time separating neutral ideas toward justice and sentencing from their own personal biases. The Judicial Sceptics believe that, due to the influence of the personal biases, judges crusade against crimes based upon their own sense of right and wrong. Judicial Sceptics agree that there is disparity in judicial sentences. They also believe this leads to "judge-shopping."

The perception of the Judicial Sceptics regarding the purpose of judicial sentencing differs from that of respondents who loaded on the other factors. Judicial Sceptics are supportive of individuality in sentencing, stemming from their belief that criminals can be rehabilitated. As a result, Sceptics tend to downplay the doctrine that punishment is the main purpose of sentencing. For the Judicial Sceptic this includes downplaying public demands for revenge and the view that isolation of criminals is necessary for maintaining order in society. This may explain why Sceptics believe that other professions in society could do as well as judges in sentencing criminals.

\section{Judicial Advocates}

The third group of respondents that may be typed into a specific factor is labelled Judicial Advocates. The demographic data on the five respondents who can be categorized as Judicial Advocates shows that they are drawn from both the public and academia (social sciences). Judicial Advocates are similar to those who loaded on the Judicial Necessity factor, but are even 
more adamant in their perception that judges are doing a good job. Judicial Advocates not only believe that judges are responsible in their decisions, but think that those decisions are based upon a well formulated concept of justice. They think judges perform this function better than could other professionals. Advocates favor a judicial system that allows the members of the judiciary the freedom to use their discretion and impose sentences that are tailored to the crime and the criminal. Judicial Advocates also go beyond those in the Judicial Necessity group as proponents of the view that judges do not allow their own personal biases to influence their sentencing decisions.

One possible reason why Advocates so wholeheartedly support the actions of members of the judiciary may be their rather tough approach to the purpose of sentencing. Advocates have a tendency to believe that a major purpose of sentencing is to isolate criminals from the rest of society. Furthermore, while believing in rehabilitation as an ideal, it is their opinion that many criminals are not candidates for rehabilitation. This may help to explain their view that sentences should be harsh enough to demonstrate the price that must be paid for committing crimes. In taking a hard line on crime and supporting harsh sentences, Advocates may feel a sense of relief in their conviction that judges are very conscientious and fair in fulfilling their duties.

Judicial Advocates believe that if disparity exists in the sentences imposed by different judges, it is the judges-not the legislature-who should take the blame. This view is reinforced by the Advocates' view that more thought may be needed in order to make the proper decision, especially since Advocates believe that judges should consider why a crime was committed prior to the sentencing decision. With the exception of why a crime was committed, Advocates think that extra-legal factors should not play a role in the sentencing decision.

\section{Discussion and Conclusion}

The results of the Q-sort were not wholly consistent with expectations. It was hypothesized that there would be several factors indicating different perceptions of the sentencing process at the end of the exercise, and there were. A second part of the hypothesis, that some jurists and some members of each of the other groups of participants would load on several of the same factors, did not develop fully. All of the members of the judiciary and their counterparts in the legal community loaded on the same factor, Judicial Necessity. 
One sign of health in the judicial system that somewhat redeems the original hypothesis is provided by the two members of the public who did load on the same factor with members of the judiciary and the legal community. This illustrates that even with a small sample such as this, the judicial and legal communities are not completely isolated from members of the public in their perceptions of the sentencing process. This suggests that at least some of the public may provide linkage with, and thereby accord legitimacy to, the decisions of those jurists that have a similar outlook toward sentencing.

The fact that the largest differences in the subjective perceptions of the respondents were between factors two and three-the Judicial Sceptics and the Judicial Advocates-also may lend itself to stability for state criminal courts. Since the respondents in this study who loaded on these two factors came from the public and from academia, this leaves the judiciary who loaded on the Judicial Necessity factor in the position of mediating between the more extreme views of the other factor types. This situation suggests a professional mediation that should help to keep the views of the Judicial Sceptics or the Judicial Advocates from dominating judicial sentencing. If the views of either the Judicial Sceptics or Judicial Advocates became dominant and unchallenged, it could create a crisis of confidence harming the ability of state criminal courts to function under increased scepticism or the demands for greater professionalism.

The study shows that the major differences of opinion between the three factor types that were isolated do not center around whether legal and extra-legal factors concerning the crime and the criminal should influence the sentencing decision. All groups were, for the most part, stable in their attitude that legal factors should, and extra-legal factors should not, be considered in the sentencing decision. This finding reaffirms previous research (Hagan and Bumiller 1983). One small difference here did separate members in the Judicial Necessity category from the others. This was the fact that this group placed more of an emphasis on prior records than did members of the other types.

This study suggests that future research is needed to examine why the judiciary and legal community shared a common subjective perception of the sentencing process. One possible direction for future exploration may be an examination of the legal socialization process in law schools. Another possible direction is suggested by the literature on political parties, which examines differences between party professionals and amateurs (Wilson 1962). This literature points to a more pragmatic approach to politics by party professionals compared to a more idealistic perspective of party amateurs. Perhaps the subjective perceptions of members of the judiciary 
and legal community are driven by pragmatic views developed by hands-on experience in the judicial process. In contrast, Judicial Advocates and Sceptics both revealed information that suggest that their perceptions concerning sentencing were shaped by more generalized principles or ideas.

The results of this study, including the inability to validate the hypothesis in its entirety, show that additional hypotheses and research must come forward to explain why state courts maintain public confidence and legitimacy in the area of criminal sentencing. At the same time, the implications of this study allow the assumption that the judicial system can expect to enjoy its present amount of support from the public, despite divisions in the public and elite legal perceptions of the criminal sentencing process.

\section{TECHNICAL NOTE}

Q-technique allows the individual to model his or her subjectivity in the form of distributions of scores which are personal but which are subject to the law of error. The common practice in Q-technique is as follows. The individuals of a P-sample perform Q-sorts. The Q-sorts are recorded, correlated, and factored. The factor loadings are rotated to an acceptable solution and finally a set of factor scores is estimated for each factor. A factor is acceptable if the Q-sorts of two or more respondents are loaded on it significantly. All factor scores are pure numbers. The individual factor score for each participant is comparable, zero being the same absolute value for all participants (Stephenson 1967, 11).

The small number of cases (persons) employed in Q-technique studies often results in questions concerning issues of generalizability. Q-technique differs from survey research because generalizations are not best thought of in terms of sample and universe. In studies using Q-technique the subjects who participate in the Q-sorts have the status of variables. The sample elements in Q-technique refers to the set of items in the Q-sample. The generalizations made in Q-technique are expected to be valid for all persons who significantly load on the same factor. Due to the nature of the generalizations made in Q-techniques it is normally not necessary to obtain large numbers to define each factor. Reliable factors scores normally can be determined when four or five participants are significantly loaded on the same factor (Brown 1980, 260). Identification of separate factors then allows for general statements, concerning differences in attitude regarding the subject under examination, to be made for each factor. The generalizations that can be made from Q-technique do not include estimates regarding what proportion of the population belongs in one factor rather than another. Such information is best determined by the use of other statistical methods and sampling procedures.

Q-technique does not rely upon randomly selected participants from a defined population who are selected by probability, area, or stratification principles. Instead, participants included in the $\boldsymbol{P}$ sample in Q-technique studies are selected with the intent of representing interests which are theoretically relevant to the problem under consideration (Stephenson 1967,203). Such consideration of experimental design principles in selecting participants make the P-sample more nearly theoretical or dimensional than random or accidental. Within this experimental design of the P-sample it is rarely necessary to have complete balance. The main desire is to include the selection of persons whose viewpoints are relevant to the matter under examination (Brown 1980, 192). 


\section{APPENDIX TABLE 1. Q-Sample and its Structure}

\section{Category: Community Values}

1. The sensibility of the public to the nature of a crime should be considered by the sentencing judge.

2. Judges should reflect society's attitudes in their sentencing decisions.

3. Because all sentences for the same crime should be consistent throughout a state, judges should not pay attention to local attitudes and values in sentencing.

4. Judicial decisions should be isolated from public opinion.

\section{Category: Judicial Process}

5. Judicial sentencing is a fundamental component of the humanistic tradition.

6. Even though there are few if any rules, standards, or guidelines to guide the exercise of sentencing discretion, it has not harmed the public's respect for the law.

7. The sentencing decision is usually a reflection of a well thought out formula of justice by the judge.

8. There is no requirement that the sentence imposed by judges have any rational basis whatsoever.

9. The actual sentencing decision is swift because the process of reaching it is not reflective or orderly.

10. Sentencing disparity is contrary to our commitment to the evenhanded administration of the law.

11. An inflexible, mechanical sentencing process, such as a mandatory sentence for each crime, would not be reflective of our system's sense of justice.

12. There should be a set sentence for every crime with no variation.

13. At the trial level, the state of sentencing and the disparity that results between judges contributes to "judge shopping" in hopes of finding a lenient judge.

14. The imposition of a sentence is a grave matter which more thought should go into.

\section{Category: Extra-Legal Sentencing Factors}

15. In imposing sentences judges should normally consider a defendant's age.

16. Marital status is a legitimate factor to consider in the sentencing process.

17. Defendants with less formal education may be more likely to be repeat offenders, nevertheless, this shouldn't be considered by judges in their sentencing decisions.

18. Unemployed defendants with no standing in the community are more likely to commit other crimes in the future, therefore, judges should consider employment prior to sentencing.

19. There is good reason to suspect that severity or leniency in sentencing may be influenced by racial prejudices.

20. Even though sex should not be a consideration in sentencing it is.

\section{Category: Legal Sentencing Factors}

21. Defendants who give state's evidence should be treated benevolently during sentencing.

22. Incarceration should be mandatory for those who commit offenses using a dangerous weapon.

23. Defendants should be given leniency if they plead guilty rather than going through the public expense of a jury trial. 


\section{APPENDIX TABLE 1 (continued)}

24. A defendant's prior record is a good indication of their future behavior and should be considered in the sentencing decision.

25. Judges should consider the circumstances of why a crime was committed.

26. Because defendants are sentenced for only the particular crime for which they were convicted, prior criminal records should not be included as part of the sentencing decision.

27. Plea bargaining allows criminals to get off easy and should be stopped.

28. In imposing sentences judges should not impose the absolute maximum sentence unless the crime is particularly heinous or brutal.

\section{Category: Judges' Capability and Training}

29. Judges are the people most capable of evaluating and sentencing criminals due to their training.

30. The legislature, not judges, should take the blame if there is disparity in sentencing.

31 . The great majority of judges perform their sentencing duties in a responsible and diligent manner.

32. Judges do a better job of sentencing than could social workers, educators, sociologists, or psychologists.

33. Some judges crusade against certain crimes which they feel disposed to stamp out by the use of drastic sentences.

34. It is not possible to avoid the impression that the judge's sense of good and evil are playing a significant part in their sentencing decision.

35. Even when two judges agree on justification for a sentence, they may impose sentences with wide disparity.

36. Judges tend to impose sentences based on their own political, moral or social views.

37. The sentencing patterns of judges reflect no understanding of complex social problems.

\section{Category: Purpose of Sentencing}

38. The process of sentencing gives criminals an awareness of their public responsibilities.

39. Sentencing is in large part concerned with avoiding future crimes by rehabilitating defendants that have been convicted.

40. The main purpose of sentencing is to promote respect for the law.

41. Sentencing does not work because it does not succeed in reducing the inclinations of the criminal mind.

42. The longer someone stays in prison, the more chance there is that they will commit more crimes upon their release.

43. Many people who are convicted of crimes are not candidates for any form of rehabilitation.

44. Sentencing is necessary to isolate criminals from the rest of society.

45. Sentences should be harsh enough to satisfy public desires for revenge against the criminal.

46. Sentencing should be harsh enough to demonstrate to other potential criminals the "price" they will pay for similar crimes. 


\section{Appendix Table 2. Simple Structure Matrix}

\begin{tabular}{llll}
\hline & & & \\
Factors & Biographical Information
\end{tabular}

Type I

$\begin{array}{llr}11 & .497 & .172 \\ 12 & .702 & .099 \\ 13 & .723 & .089 \\ 14 & .723 & -.021 \\ 15 & .710 & .035 \\ 16 & .773 & -.055 \\ 17 & .793 & .196 \\ 19 & .645 & -.076 \\ 20 & .678 & -.264 \\ 21 & .439 & -.231 \\ 22 & .602 & -.175 \\ 23 & .375 & -.195 \\ 25 & .718 & -.160 \\ 26 & .615 & -.382 \\ 27 & .598 & -.151 \\ 28 & .631 & -.311 \\ 29 & .761 & .180\end{array}$

female, law professor

male, law professor

male, law professor

male, law professor

female, law professor

male, law professor

male, law professor

male, law professor

male, law professor

female, school teacher

male, minister

male, circuit judge

male, circuit judge

male, circuit judge

male, circuit judge

male, circuit judge

male, circuit judge

Type II

$\begin{array}{rrr}1 & -.109 & .678 \\ 6 & .247 & .614 \\ 7 & .098 & .551 \\ 10 & .352 & .566 \\ 30 & .281 & .641\end{array}$

Type III

$\begin{array}{rll}2 & .242 & -.480 \\ 3 & .094 & -.232 \\ 5 & .456 & -.523 \\ 9 & .317 & -.402 \\ 24 & .275 & -.373\end{array}$

Non-significant or Compounding

$\begin{array}{rrrl}4 & -.358 & .303 & \text { female, Ph.D } \\ 8 & -.139 & .207 & \text { male, Ph.D } \\ 18 & .082 & -.177 & \text { female, law professor } \\ 31 & .402 & .449 & \text { female, student }\end{array}$

female, secretary male, Ph.D. male, Ph.D. male, store clerk male, student

female, housewife female, Ph.D. male, Ph.D. female, Ph.D. female, housewife 


\section{REFERENCES}

Brown, Stephen R. 1980. Political Subjectivity. New Haven: Yale University Press.

Caldeira, Gregory A. 1986. Neither the Purse nor the Sword: The Dynamics of Public Confidence in the United States Supreme Court. American Political Science Review 80: 1209-1226.

1987. Public Opinion and the U.S. Supreme Court: FDR's Court-Packing Plan. American Political Science Review 81: 1139-1153.

Casey, Gregory. 1989. Public Perceptions of Judicial Scandal: The Missouri Supreme Court 19821988. The Justice System Journal 13: 284-307.

Cook, Beverly B. 1979. Judicial Policy: Change Over Time. American Journal of Political Science 23: 208-14.

1977. Public Opinion and Federal Judicial Policy. American Journal of Political Science 21: 567-600.

Easton, David. 1965. A Systems Analysis of Political Life. New York: John Wiley and Sons.

Hagan, John and Kristin Bumiller. 1983. Making Sense of Sentencing: A Review and Critique of Sentencing Research. In Alfred Blumstein, ed., Research on Sentencing: The Search for Reform. Washington DC: National Academy Press.

Handberg, Roger. 1984. Public Opinion and the United States Supreme Court, 1935-1981. International Social Science Review 59: 3-13.

Hardy, Richard. 1985. Missouri Courts, Judges, and Juries. In Richard J. Hardy and Richard R. Dohm, eds., Missouri Government and Politics. Columbia, MO: University of Missouri Press.

Jackman, Robert W. 1981. Political Elites, Mass Publics, and Support for Democratic Principles. In Norman R. Luttbeg, ed., Public Opinion and Public Policy. Itasca, IL: F.E. Peacock Publishers, Inc.

Jaros, Dean and Robert Roper. 1980. The United States Supreme Court: Myth, Diffuse Support, Specific Support, and Legitimacy. American Politics Quarterly 8: 85-105.

Kuklinski, James and John Stanga. 1979. Political Participation and Government Responsiveness: The Behavior of California Superior Courts. American Political Science Review 73: 10901099.

Neubauer, David W. 1991. Judicial Process: Laws, Courts, and Politics in the United States. Pacific Grove, CA: Brooks/Cole Publishing Co.

Thompson, G. C. 1966. The Evaluation of Public Opinion. In Bernard Berelson and Morris Janowitz, eds., Reader in Public Opinion and Communication. New York: Free Press.

Stephenson, William. 1953. The Study of Behavior. Chicago: University of Chicago Press. Press. 1967. The Play Theory of Mass Communication. Chicago: University of Chicago

Tanenhaus, Joseph and Walter Murphy. 1981. Patterns of Public Support for the Supreme Court: A Panel Study. Journal of Politics 43: 24-39.

Ungs, Thomas D. and Larry R. Baas. 1972. Judicial Role Perceptions: A Q-Technique Study of Ohio Judges. Law and Society Review 6: 343-367.

Wilson, James Q. 1962. The Amateur Democrat: Club Politics in Three Cities. Chicago: University of Chicago Press.

Yankelovich, Skelly and White, Inc. 1978. Highlights of a National Survey of the General Public, Judges, Lawyers, and Community Leaders. In T. Fetter, ed., State Courts: A Blueprint for the Future. Williamsburg, VA: National Center for State Courts. 